\title{
Comparison of Cutting Diathermy and Scalpel in Terms of Delay in Wound Healing and Scar Appearance in Skin Incision: A Prospective Observational Study
}

\author{
Deri İnsizyonunda Yara İyileșmesinde Gecikme ve Skar Görünümü Açısından Bistüri \\ ile Koterin Karșılaştırılması: Prospektif Gözlemsel Çalıșma
}

(D) Alpaslan Kaban, (D) Ayça Küçükyurt, (D) Ayça Durmuş, (D) Işık Kaban, (D) Fatma Ferda Verit

İstanbul Training and Research Hospital, Clinic of Obstetrics and Gynecology, i̇stanbul, Turkey

\begin{abstract}
Introduction: Traditionally, a scalpel is used for surgical incisions. The aim of this study was to compare cutting diathermy and scalpel in terms of wound healing or cosmetic appearance in skin incision.

Methods: The study was performed in patients with Pfannenstiel incision in a gynecology and obstetrics clinic. Half of the skin incision of the same patient was made with cautery and the other half was made with scalpel. The part of the incision made with cautery was compared with the incision made with scalpel in terms of wound healing and cosmetic appearance. The assessments were based on the observer scale of the "The Patient and Observer Scar Assessment scale" (POSAS). Evaluations were performed as single blind (observerblinded, but not surgeon) in the short term (postoperative 15th day) and long term ( $45^{\text {th }}$ day).

Results: A total of 73 women with Pfannenstiel incision were evaluated. The median age of the patients was 33 (21-52) years. The total POSAS scores of the parts opened with scalpel were not statistically different from those opened with cautery both at the $15^{\text {th }}$ and $45^{\text {th }}$ days $\left(27.3 \pm 5.2\right.$ vs $27.0 \pm 5.1, p=0.88$ for $15^{\text {th }}$ day; $11.8 \pm 3.2$ vs $11.0 \pm 4.1, p=0.56$ for $45^{\text {th }}$ day).

Conclusion: The study showed that using cautery in cutting mode had no effect on poor wound healing and cosmetic appearance in Pfannenstiel incisions compared to the use of scalpel. This result encourages surgeons to make a skin incision with cautery.
\end{abstract}

Keywords: Incision, scalpel, cautery, scar $\ddot{0 Z Z}$

Amaç: Geleneksel olarak, cerrahi insizyonlar için bir bistüri kullanılır. Bu çalıșmanın amacı, yara iyileșmesi ve deri insizyonunun kozmetik görünümü açısından koter ile bistüriyi karşılaştırmaktır.

Yöntemler: Çalıșma kadın hastalıkları ve doğum kliniğinde Phannenstiel insizyonu olan hastalarda yapıldı. Aynı hastanın deri insizyonunun yarısı koterin kesme modu ile, diğer yarısı neșter ile açıldı. Koter ile açılan insizyon kısmı, yara iyileșmesi ve kozmetik görünüm açısından neşter ile açılan kısım ile karşılaștırıldı. Değerlendirmeler POSAS (Hasta ve Gözlemci Skar Değerlendirme ölçeği) puanlama ölçeğinin gözlemci kısmına dayandırılmıştır. Değerlendirmeler kısa vadede (postoperatif 15. gün) ve uzun vadede (45. gün) tek kör (gözlemci kör fakat cerrah değil) olarak yapıldı.

Bulgular: Pfannenstiel insizyonu olan toplam 73 hasta değerlendirildi. Hastaların ortanca yașı 33 (21-52) idi. Bistüri ile açılan bölümlerin toplam POSAS skorları, 15. ve 45. günlerde koter ile açılanlara göre istatistiksel olarak farklı değildi (15. gün için $27,3 \pm 5,2$ ve $27,0 \pm 5,1 p=0,88 ; 45$. gün için $11,8 \pm 3,2$, $p=0,56)$.

Sonuç: Çalışma, bistüri kullanımı ile karşılaştırıldığında, kesme modu koter kullanımının, Pfannenstiel insizyonlarında kötü yara iyileșmesi ve kozmetik görünüm olarak bir etkisi olmadığını göstermiștir. Bu sonuç, cerrahları koter ile deri insizyonu açmaya teșvik eder.

Anahtar Kelimeler: Insizyon, bisturi, koter, skar Observational Study. İstanbul Med J 2019; 20(4): 338-41.

(c) Copyright 2019 by the Istanbul Training and Research Hospital/istanbul Medical Journal published by Galenos Publishing House.

(C) Telif Hakkı 2019 istanbul Eğitim ve Araștırma Hastanesi/Istanbul Tıp Dergisi, Galenos Yayınevi tarafından basılmıștır. 


\section{Introduction}

Today, electrosurgical instruments are widely used in surgical procedures. Many publications have reported that the use of electrocautery is acceptable instead of traditional scalpel, even for skin incision (1-7). On the other hand, there are concerns about the use of diathermy in the skin incision due to fear of causing large scars and improper tissue healing (8-10).

In this study, scalpel and electrocautery were compared in terms of wound healing and cosmetic appearance. The difference of this study from previous studies is that these two techniques are compared in the same patient, thus eliminating the patient-related parameters.

\section{Methods}

This study was carried out between June 2018 and November 2018 in Gynecology and Obstetrics Clinic of Istanbul Training and Research Hospital. Local Clinical Research Ethics Committee approval was obtained for the study (decision no: 2011-KAEK-50). Patients scheduled for operation with a Pfannenstiel incision were selected as the study cohort. Exclusion criteria were a previous Pfannenstiel incision, morbid obesity, diabetes, patients aged 65 years and older, patients under 15 years of age, presence of any skin disease at the incision site. Informed consent was obtained from the patients for the study.

Half of the skin incision of the same patient was made with electrocautery in cutting mode (40-50 watt) and the other half was made with scalpel in order to obtain two identical observation sites. The part of the incision made with cautery (right side) was compared with the part made with scalpel (left side). Comparisons were made as single blind (observer- blinded, but not surgeon) when the patient came for control on the $15^{\text {th }}$ and $45^{\text {th }}$ days. Evaluated parameters were delayed wound healing and scar appearance. Patient and Observer Scar Assessment scale (POSAS) v2.0 observer scale was used for these evaluations. The observer scale of the POSAS consists of six items (vascularity, pigmentation, thickness, relief, pliability and surface area). All items are scored on a scale ranging from 1 ("like normal skin") to 10 ("worst scar imaginable"). The sum of the six items results in a total score of the POSAS observer scale. All parameters should preferably be compared to normal skin on a comparable anatomic location. The total minimum score of the POSAS scale is 6 and the maximum score is 60 . Observations were made by the same team throughout the study.

\section{Statistical Analysis}

Mean and standard deviation for POSASscore, and median and minimummaximum values for age of the patients were used for descriptive statistics. Shapiro-Wilk test was used for normality distribution of groups. Chi-square test was used for the analysis of qualitative independent data. SPSS 22.0 program was used in the analysis. A $p$ value $<0.05$ was considered to indicate statistical significance.

\section{Results}

A total of 73 patients with Pfannenstiel incision were evaluated. The median age of the patients was 33 (21-52) years. The total POSAS scores of the incision parts made with scalpel were not statistically different from those made with cautery both at the $15^{\text {th }}$ and $45^{\text {th }}$ days $(27.3 \pm 5.2$ vs $27.0 \pm 5.1 p=0.88$ for $15^{\text {th }}$ day; $11.8 \pm 3.2$ vs $11.0 \pm 4.1 p=0.56$ for $45^{\text {th }}$ day) (Tables 1 and 2) (Figures 1-4).

\begin{tabular}{|c|c|c|c|}
\hline & Cautery & Scalpel & $\mathrm{p}^{*}$ \\
\hline Vascularity & $6.4 \pm 2.0$ & $5.3 \pm 1.6$ & 0.08 \\
\hline Pigmentation & $2.3 \pm 0.4$ & $2.3 \pm 0.9$ & 0.98 \\
\hline Thickness & $4.6 \pm 1.8$ & $4.8 \pm 1.0$ & 0.90 \\
\hline Relief & $4.5 \pm 0.2$ & $4.6 \pm 0.9$ & 0.56 \\
\hline Pliability & $4.0 \pm 0.7$ & $4.4 \pm 0.1$ & 0.27 \\
\hline Surface area & $5.5 \pm 1.0$ & $5.6 \pm 0.7$ & 0.91 \\
\hline Total score of the POSAS & $27.3 \pm 5.2$ & $27.0 \pm 5.1$ & 0.88 \\
\hline
\end{tabular}

\section{Table 2. Comparison of long term $\left(45^{\text {th }}\right.$ day) the patient and observer scar assessment scale scores (mean \pm standart deviation) of cautery} and scalpel

\begin{tabular}{|c|c|c|c|}
\hline & Cautery & Scalpel & $p^{*}$ \\
\hline Vascularity & $1.4 \pm 0.3$ & $1.3 \pm 1.1$ & 0.85 \\
\hline Pigmentation & $2.4 \pm 0.4$ & $2.0 \pm 0.9$ & 0.08 \\
\hline Thickness & $1.6 \pm 1.7$ & $1.1 \pm 1.0$ & 0.78 \\
\hline Relief & $3.1 \pm 0.4$ & $2.7 \pm 0.9$ & 0.76 \\
\hline Pliability & $1.0 \pm 0.8$ & $1.4 \pm 0.1$ & 0.27 \\
\hline Surface area & $2.3 \pm 1.0$ & $2.5 \pm 0.7$ & 0.51 \\
\hline Total score of the POSAS & $11.8 \pm 3.2$ & $11.0 \pm 4.1$ & 0.56 \\
\hline
\end{tabular}




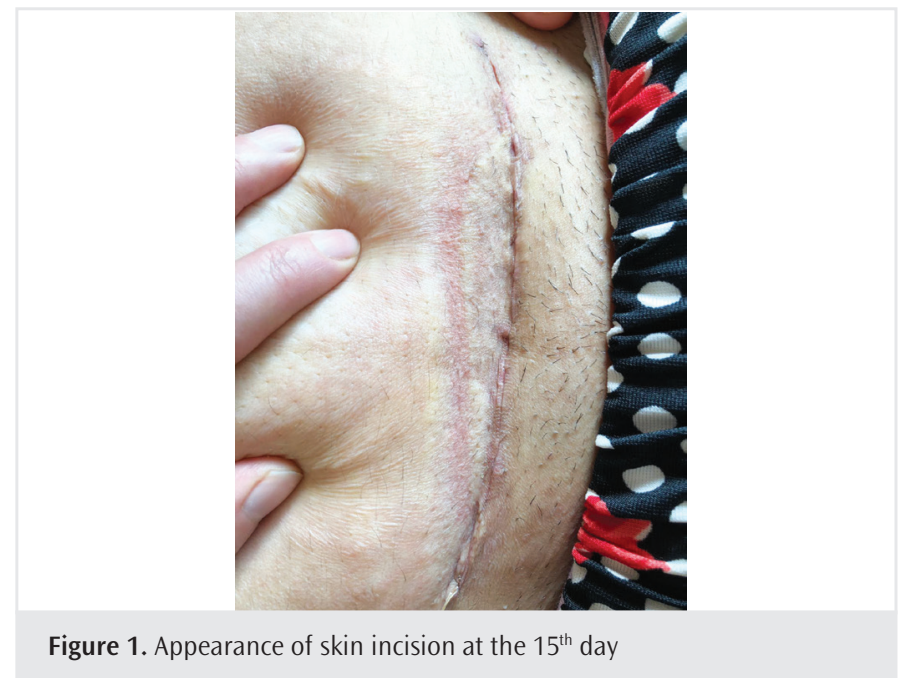

Figure 1. Appearance of skin incision at the $15^{\text {th }}$ day

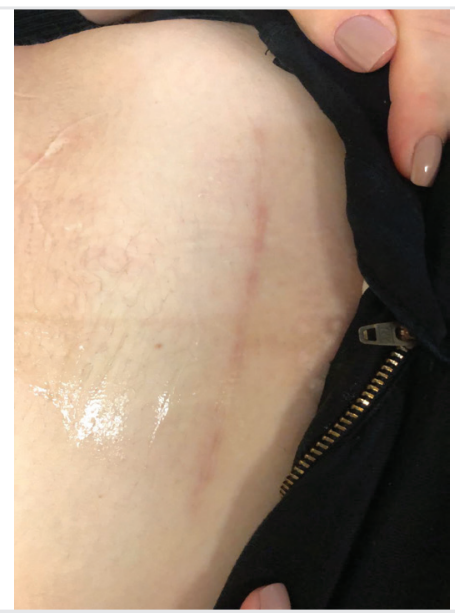

Figure 3. Long-term ( $45^{\text {th }}$ day) appearance

\section{Discussion}

In this study, half of the Pfannenstiel skin incision in the same patient was made with an electrocautery and the other half with a scalpel. These two halves were compared at the $15^{\text {th }}$ and $45^{\text {th }}$ days. According to the results of the study, the effects of cautery and scalpel on wound healing and cosmetic were not different.

In the literature, many studies have compared the scalpel with cautery in skin incision. These studies have shown that these two techniques have similar cosmetic and wound healing results (1-7). The difference of this study is that these two techniques are compared in the same patient. With this comparison method, the parameters affected by the differences between the patients were eliminated. This study, unlike the previous studies, is a self-controlled study. Each case is its own control, thus the conditions that could affect wound healing are equalized.

The stages of wound healing proceed in an organized way and follow four processes: hemostasis, inflammation, proliferation and maturation., Angiogenesis, fibroplasia and re-epithelialization occur in the proliferation phase $(11,12)$. The proliferation phase in a wound healing process is completed in the first two weeks (13). The maturation phase, also referred as the remodeling phase of wound healing, is

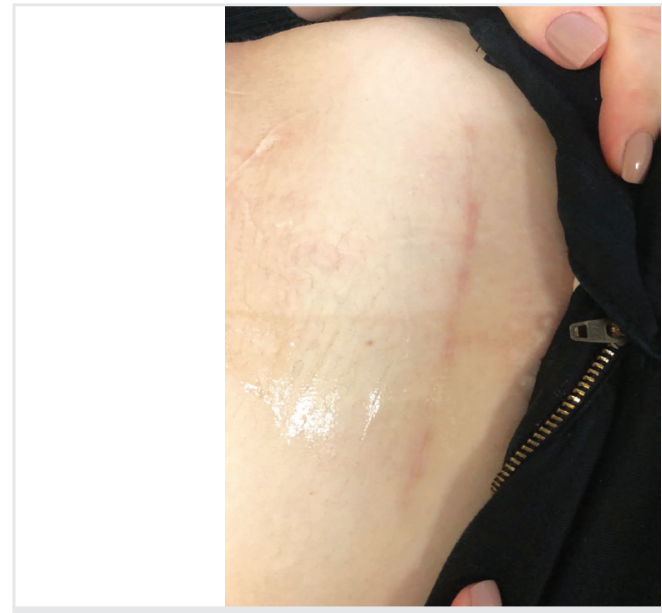

Figure 2. Appearance of skin incision at the $45^{\text {th }}$ day

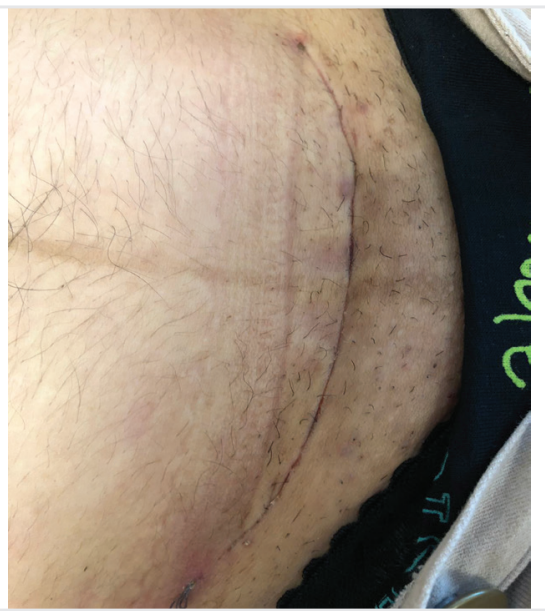

Figure 4. Appearance of skin at the $15^{\text {th }}$ day

when the collagen is remodeled from type 3 to type 1 and the wound is completely closed. Generally, remodeling begins approximately 21 days after an injury and can last for months (11-13). In the present study, the surgical incision was evaluated at two separate times. The initial evaluation was performed at the $15^{\text {th }}$ day when the proliferative phase was completed. In addition, patients were evaluated at the sixth week $\left(45^{\text {th }}\right.$ day) when they were called for a follow-up examination.

\section{Conclusion}

POSAS patient scale was not used. The patients had difficulty in evaluating both halves of the Pfannenstiel incision separately and did not provide any objective results. Therefore, POSAS observer scale was used for evaluations.

In this study, it was observed that the use of cautery in cutting mode in Pfannenstiel incisions had no effect on poor wound healing and poor cosmetic. In fact, surgeons have experienced that the use of cautery for incision is more advantageous for bleeding control. This result of the study encourages surgeons to make a skin incision with a cautery.

Ethics Committee Approval: İstanbul Training and Research Hospital, Clinical Research Ethics Committee (decision no: 2011-KAEK-50). 
Informed Consent: Informed consent was obtained from the patients for the study.

Peer-review: Externally peer-reviewed.

Author Contributions: Concept - A.K., A.D., A.KÜ. F.F.V.; Design - A.K., A.D., A.KÜ. F.F.V.; Supervision - A.K., A.D., A.KÜ. F.F.V.; Materials - A.K., A.D., A.KÜ. F.F.V.; Data Collection and/or Processing - A.K., A.D., A.KÜ. F.F.V.; Analysis and/ or Interpretation - A.K., A.D., A.KÜ. F.F.V.; Literature Search - A.K., A.D., A.KÜ., F.F.V., I.K.; Writing Manuscript - A.K., A.D., A.KÜ. F.F.V.; Critical Review - A.K., A.D., A.KÜ. F.F.V.

Conflict of Interest: No conflict of interest was declared by the authors.

Financial Disclosure: The authors declared that this study received no financial support.

\section{References}

1. Shamim M. Diathermy vs. Scalpel skin incisions in general surgery: Doubleblind, randomized, clinical trial. World J Surg 2009; 33: 1594-9.

2. Ly J, Mittal A, Windsor J. Systematic review and meta-analysis of cutting diathermy versus scalpel for skin incision. Br J Surg 2012; 99: 613-20.

3. Elbohoty AE, Gomaa MF, Abdelaleim M, Abd-El-Gawad M, Elmarakby M. Diathermy versus scalpel in transverse abdominal incision in women undergoing repeated cesarean section: A randomized controlled trial. J Obstet Gynaecol Res 2015; 41: 1541-6.

4. Prakash LD, Balaji N, Kumar SS, Kate V. Comparison of electrocautery incision with scalpel incision in midline abdominal surgery - A double blind randomized controlled trial. Int J Surg 2015; 19: 78-82.
5. Franchi M, Ghezzi F, Benedetti-Panici PL, Melpignano M, Fallo L, Tateo S, et al. A multicentre collaborative study on the use of cold scalpel and electrocautery for midline abdominal incision. Am J Surg 2001; 181: 128-32.

6. Ayandipo 00, Afuwape 00, Irabor D, Oluwatosin OM, Odigie V. Diathermy versus scalpel incision in a heterogeneous cohort of general surgery patients in a Nigerian teaching hospital. Niger J Surg 2015; 21: 43-7.

7. Stupart DA, Sim FW, Chan ZH, Guest GD, Watters DA. Cautery versus scalpel for abdominal skin incisions: A double blind, randomized crossover trial of scar cosmesis. ANZ J Surg 2016; 86: 303-6.

8. Kearns SR, Connolly EM, McNally S, McNamara DA, Deasy J. Randomized clinical trial of diathermy versus scalpel incision in elective midline laparotomy. Br J Surg 2001; 88: 41-4.

9. Scott JE, Swanson EA, Cooley J, Wills RW, Pearce EC. Healing of canine skin incisions made with monopolar electrosurgery versus scalpel blade. Vet Surg 2017; 46: 520-9.

10. Madden JE, Edlich RF, Custer JR, Panek PH, Thul J, Wangensteen OH. Studies in the management of the contaminated wound. IV. Resistance to infection of surgical wounds made by knife, electrosurgery, and laser. Am J Surg 1970; 119: $222-4$.

11. Greaves NS, Ashcroft KJ, Baguneid M, Bayat A. Current understanding of molecular and cellular mechanisms in fibroplasia and angiogenesis during acute wound healing. J Dermatol Sci 2013; 72: 206-17.

12. Li J, Chen J, Kirsner R. Pathophysiology of acute wound healing. Clin Dermatol 2007; 25: 9-18.

13. Gonzalez ACDO, Costa TF, Andrade ZDA, Medrado ARAP. Wound healing - A literature review. Ana Bras Dermatol 2016; 91: 614-20. 